\title{
KESULITAN BELAJAR PERPAJAKAN BERPENGARUH TERHADAP MOTIVASI BELAJAR MAHASISWA AKUNTANSI DALAM MATA KULIAH PERPAJAKAN
}

\author{
Atiqah Azizah \\ Politeknik Negeri Bengkalis \\ e-mail : atiqahazizah47@gmail.com
}

\begin{abstract}
Abstrak
Penelitian ini bertujuan untuk mengetahui signifikan pengaruh kesulitan belajar perpajakan terhadap motivasi belajar mahasiswa. Populasi pada penelitian adalah mahasiswa Politeknik Negeri Bengkalis Prodi Akuntansi Keuangan Publik pada Semester Genap TA 2016/2017 sebanyak 55 mahasiswa dilibatkan menjadi subjek penelitian. Alat uji yang digunakan adalah uji nonparametrik MannWhiteney. Hasil penelitian ini adalah tidak ada pengaruh yang signifikan kesulitan belajar perpajakan terhadap motivasi belajar mahasiswa. Impikasi terapan yang diberikan para pengajar memperhatikan kesulitan belajar yang dihadapi peserta didik dalam kegiatan pembelajaran, mahasiswa perlu memiliki motivasi belajar yang harus selalu ditingkatkan secara berkesinambungan dalam mencapai tujuan pembelajaran.
\end{abstract}

Kata kunci: Kesulitan Belajar, Motivasi Belajar, Hasil Belajar, Perpajakan.

\begin{abstract}
This study aims to determine the effect of tax learning difficulties on student motivation. The population in the study were Bengkalis State Polytechnic students Public Financial Accounting Study Program in the Even Semester 2016/2017 Semester as many as 55 students were involved as research subjects. The test tool used was the Mann-Whiteney nonparametric test. The results of this study are that there is no significant effect on taxation learning difficulties on student learning motivation. Applied implications given by the instructor pay attention to the learning difficulties faced by students in learning activities, students need to have motivation to learn that must be continuously improved in achieving learning goals.
\end{abstract}

Keywords: Learning Difficulties, Learning Motivation, Learning Outcomes, Taxation 
Jurnal Cendekia Akuntansi

pISSN 2723-0104

Volume 1, Nomor 2

eISSN 2723-0090

Kediri, Desember 2020

\section{PENDAHULUAN}

Keberhasilan mahasiswa dalam menempuh pembelajaran perkuliahan dilihat dari nilai hasil belajar. Hasil belajar yang baik dapat membuat mahasiswa bersemangat, antusias dan termotivasi dalam belajar. Apabila mahasiswa memiliki motivasi belajar yang tinggi akan mudah memperoleh materi pembelajaran, motivasi belajar dapat memberikan konstribusi yang signifikan terhadap keberhasilan belajar mahasiswa. Akan tetapi dalam proses pembelajaran, banyak mahasiswa yang mengalami kesulitan dalam mempelajari materi. Kesulitan ini yang merupakan faktor penghambat kegiatan belajar bagi mahasiswa. Mahasiswa yang mengalami kesulitan belajar susah menyerap materi dari dosen. Sehingga hasil pembelajaran dapat menjadi rendah. Hal ini berarti kesulitan belajar merupakan aspek yang merugikan mahasiswa dalam proses kegiatan belajar.

Pada Prodi Akuntansi Keuangan Publik terdapat mata kuliah perpajakan 1 yang merupakan salah satu kuliah pokok dalam kurikulum. Mata kuliah ini adalah membekali mahasiswa pengetahuan perpajakan secara mendasar. Setiap perkuliahan pepajakan para mahasiswa selalu menunjukan motivasi yang tinggi. Tampak dari sikap antusias, minat belajar serta tanggapan positif dari mahasiswa dalam mengikuti perkuliahan perpajakan.

Dengan memperhatikan motivasi belajar mahasiswa yang tinggi terhadap materi-materi perpajakan diharapkan mahasiswa dapat mencapai hasil belajar yang tinggi. Kenyataan yang terjadi justru berbeda dari yang diharapkan, sebagian mahasiswa memperoleh nilai yang rendah pada ujian akhir semester untuk mata kuliah perpajakan 1. Rendahnya hasil belajar ini diduga mahasiswa mengalami kesulitan belajar pada pokok bahasan perhitungan pajak, meskipun mereka memiliki motivasi belajar yang tinggi dalam mempelajari materi perpajakan.

Berdasarkan paparan diatas, maka perlu dilakukan penelitian untuk melihat pengaruh kesulitan belajar perpajakan terhadap motivasi belajar mahasiswa. Penelitian ini dilakukan untuk mengetahui signifikan pengaruh kesulitan belajar terhadap motivasi belajar mahasiswa Akuntansi Keuangan Publik.

\section{TINJAUAN PUSTAKA}

Penelitian Terdahulu

A.Rony Yulianto dan Dewi Apriyani berjudul Kesulitan Belajar Perpajakan dan Pengaruhnya terhadap Motivasi Belajar Mahasiswa Pendidikan Ekonomi. Hasil penelitian tersebut Hasil analisis dan pembahasan menyatakan bahwa tidak ada pengaruh yang signifikan kesulitan belajar perpajakan terhadap motivasi belajar mahasiswa.Berarti tingkat kesulitan belajar perpajakan tidak dapat mengubah motivasi belajar mahasiswa. Hasil koefisien regresi linier kesulitan belajar perpajakan terhadap motivasi belajar mahasiswa sebesar $\beta$ xy $=-0,05$ dengan signifikansi 0,771 .

Cornelius Hery Setyawan (2012) berjudul peningkatan hasil belajar perpajakan melalui media taxi snaders pada siswa XI BSMKPL Tarcisius 2 
Semarang, hasil dari penelitian tersebut adalah perubahan-perubahan tingkah laku siswa yang dikehendaki benar-benar terjadi setelah siswa mengalami proses belajar. Hasil belajar siswa biasanya dinyatakan dalam skor hasil tes. Hasil belajar dalam penelitian ini dinyatakan dengan hasil pre tes yang diberikan sebelum pembelajaran dan setelah pembelajaran berakhir atau post tes. Skor yang diperoleh siswa dalam pre-tes dan post-tes dapat digunakan sebagai indikator peningkatan hasil belajar siswa pada penelitian ini. Adanya peningkatan skor siswa dari pre-tes ke post-tes dan skor siswa dari siklus I ke siklus II dapat menggambarkan peningkatan hasil belajar siswa pada ranah kognitif.

Emi Rahmawat dan Adi Darmawan Ervanto (2017) berjudul pembelajaran mata kuliah perpajakan berbasis kasus: bukti empiris dan survei. Hasil penelitian dan pembahasan. Bukti empiris menunjukkan bahwa strategi pembelajaran berbasis kasus (case based learning) pada mata kuliah perpajakan belum efektif dalam meningkatkan pemahaman mahasiswa dalam proses belajar mengajar.

\section{Teori Belajar}

Menurut Slameto (2003), belajar adalah usaha yang dilakukan seseorang untuk memperoleh suatu perubahan perilaku yang baru secara keseluruhan sebagai hasil pengalaman berinteraksi dengan lingkungannya.Sedangkan menurut Wahyuni dan Loekmono (2006) menyatakan bahwa belajar merupakan proses untuk melakukan perubahan relatif permanen dalam perilaku atau potensi perilaku seseorang sebagaihasil dari pengalaman atau latihan yang diperkuat.

Menurut Purwanto (2011) hasil belajar adalah perubahan perilaku peserta didik akibat belajar. Perubahan perilaku disebabkan karena dia mencapai penguasaan atas sejumlah bahan yang diberikan dalam proses belajar mengajar. Lebih lanjut lagi ia mengatakan bahwa hasil belajar dapat berupa perubahan dalam aspekkognitif, afektif dan psikomotorik. Sedangkan menurut Sudjana (2003) mengemukakan bahwa hasil belajar adalah perubahan tingkah laku yang mencakup bidang kognitif, afektif, dan psikomotorik yang dimiliki oleh siswa setelah menerima pengalaman belajar.

Lyness (2007), menyatakan bahwa kesulitan belajar dalah berbagai hambatan yang mempengaruhi pemikiran seseorang dalam menerima, memproses, menganalisis danmenyimpan informasi.Berarti kesulitan belajar dapat disebabkan oleh hambatan dalam faktor intellegensi (IQ).Hambatan ini dapat menjadi masalah besar bagi mahasiswa dalam melaksanakan aktivitas belajarnya. Sedangkan menurut Sudrajat (2008) mengungkapkan kesulitan belajar meliputi: 1) Learning Disorder (kekacauan belajar), 2) Learning Disfunction (Disfungsi belajar), 3) Underachiever (Prestasi di bawah standar), 4) Slow Learner (lambat belajar), 5) Learning Disabilities (Ketidakmampuan belajar). Dari pengertian tersebut dapat disimpulkan kesulitan belajar perpajakan karena hambatan yang di alami mahasiswa pada saat menerima dan mengolah materi kuliah perpajakan.

\section{Motivasi}

Menurut Wecley dan Yuki (2003), motivasi biasanya diartikan sebagai suatu proses dimana perilaku seseorang diberi penguatan dan arahan. Setiap aktivitas yang dilakukan seseorang proses yang mengarah pada suatu tujuan tertentu. Untuk dapat mencapai suatu tujuan yang diharapkan adanya aktivitas penguatan atau dorongan. Sedangkan Menurut Pujadi (2007) terdapat beberapa 
faktor yang dapat mepengaruhi motivasi belajar mahasiswa dalam mengikuti perkuliahan, antara lain: 1) faktor intrinsik mahasiswa, 2) kualitas dosen, 3) Bobot materi perkuliahan, 4) Metode Perkuliahan. Dapat disimpulkan dorongan dari dalam dan luar diri mahasiswa untuk melakukan aktivitas belajar guna mencapai prestasi yang optimal mempelajari materi perpajakan.

\section{METODE PENELITIAN}

\section{Data Penelitian}

Penelitian ini menggunakan data sekunder. Data sekunder adalah data yang telah dikumpulkan melalui sim.polbeng.ac.id. berupa nilai akhir mahasiswa dalam mata kuliah perpajakan 1

\section{Populasi}

Menganalisa nilai akhir perpajakan mahasiswa semester 2. Populasi dalam penelitian ini berjumlah 55 orang mahasiswa. Semua populasi adalah sampel atau disebut juga sampel jenuh.

\section{Variabel Penelitian}

Penelitian ini bertujuan untuk membuktikan apakah kesulitan belajar perpajakan berpengaruh terhadap motivasi belajar. Variabel yang digunakan dalam penelitian ini hanya 1 (satu) variabel, yaitu nilai akhir Perpajakan. Nilai akhir merupakan kombinasi antara hasil ujian tengah semester, hasil ujian akhir semester dan tugas.

\section{Alat Uji}

Alat uji yang digunakan untuk data normal adalah Independent Sample Ttest. Rumus Independent Sample T-test dapat direpresentasikan sebagai berikut:

$$
t=\frac{\mathrm{X}-\mu}{\left(\frac{S D}{\sqrt{N}}\right)}
$$

Keterangan:

$\mathrm{t}=$ nilai $\mathrm{t}$ hitung

$\mathrm{X}=$ rata-rata sampel

$\mu=$ nilai parameter

$\mathrm{SD}=$ standar deviasi

$\mathrm{N}=$ sampel

Untuk data yang tidak normal, alat uji yang digunakan adalah uji beda non parametrik Mann-Whitney. Kedua alat uji ini berfungsi untuk membandingkan rata-rata dari dua grup yang tidak berhubungan satu dengan yang lain, apakah kedua kelompok tersebut mempunyai rata-rata yang sama atau tidak secara signifikan. Rumus Mann-Whitney sebagai berikut:

Keterangan:

$\mathrm{U} 1=$ Statistik uji U1

$\mathrm{U} 2$ = Statistik uji U2

R1 = jumlah rank sampel 1

$\mathrm{R} 2=$ jumlah rank sampel 2

$\mathrm{n} 1$ = banyaknya anggota sampel 1 
$\mathrm{n} 2$ = banyaknya anggota sampel 2

Kriteria pengujiannya untuk uji Independent Sample T-test adalah :

1. Apabila signifikansi lebih besar dari p-value (5\%), maka Ho ditolak.

2. Apabila nilai $t$ hitung lebih tinggi dibandingkan $t$ tabel, maka Ha diterima.

3. Apabila nilai $t$ tabel lebih tinggi dibandingkan $t$ hitung, maka Ho diterima. Untuk

Uji beda non parametrik Mann Whitney U, kriteria pengambilan keputusannya adalah:

1. Apabila signifikansi lebih besar dari p-value (5\%), maka Ho ditolak

2. Jika nilai $U$ hitung $\leq U$ table atau signifikansi diatas $p$-value maka Ho ditolak, Ha diterima

3. Jika nilai U hitung > U table maka Ho diterima.

\section{HASIL DAN PEMBAHASAN}

\section{Analisis Deskriptif}

Penelitian ini dilakukan untuk mengetahui apakah kesulitan belajar perpajakan dan pengaruh motivasi belajar terdapat perbedaan mata kuliah perpajakan 1antara kelas A dan B. Hasil uji deskriptif disajikan dalam Tabel 2.

\section{Tabel 2: Hasil Uji Deskriptif}

\begin{tabular}{|c|c|c|c|c|c|}
\hline No & Kelas & Mean & Min & Max & Median \\
\hline 1 & A & 78 & 60 & 100 & 80 \\
\hline 2 & B & 80 & 65 & 100 & 80 \\
\hline
\end{tabular}

Berdasarkan Tabel 2, rata-rata nilai akhir perpajakan untuk kelas A adalah 78, sedangkan nilai kelas B yaitu 80 yang memiliki nilai lebih tinggi. Artinya, nilai rata-rata perpajakan tertinggi adalah di kelas $\mathrm{B}$.

\section{Uji Normalitas}

Pengujian normalitas data dilakukan dengan menggunakan KolmogorovSmirnov dengan alpha sebesar 5\%. Hasil uji normalitas data dapat dilihat pada Tabel 3.

Tabel 3: Hasil Uji Normalitas Kolmogorov-Smirnov

\begin{tabular}{l|c|c|c}
\hline No Item & Sig $(\mathrm{p})$ & Kolmogorov-Smirnov & Keterangan \\
\hline Kelas A & 0.00 & 0.05 & Tidak Normal \\
\hline Kelas B & 0.00 & 0.05 & Tidak Normal \\
\hline
\end{tabular}

Hasil uji normalitas menunjukkan nilai kelas A dan B tidak normal. Dengan demikian, pengujian hipotesis hanya dapat dilakukan dengan menggunakan uji nonparametrik mann-whiteney.

\section{Perbandingan Hasil Belajar Mahasiswa Kelas A dengan Kelas B}

Hasil uji Mann Whitney untuk melihat perbedaan hasil belajar antara kelas A dengan kelas B menunjukkan signifikansi sebesar 65,8\%. Signifikansi tersebut lebih besar dari pvalue 5\%, maka dapat disimpulkan hipotesa nol diterima yang artinyakesulitan belajar perpajakan dan pengaruh motivasi belajar mahasiswa 
dalam mata kuliah Pepajakan antara kelas A dengan kelas B tidak memiliki perbedaan yang signifikan.

Tabel 4.Hasil Uji Mann-Whiteney

\begin{tabular}{|l|l|l|l|}
\hline No & Variabel & Sig & Keterangan \\
\hline 1 & $\begin{array}{l}\text { Kesulitan } \\
\text { belajar }\end{array}$ & 0,658 & $\begin{array}{l}\text { Tidak } \\
\text { berbeda }\end{array}$ \\
\hline
\end{tabular}

Hasil penelitian ini menunjukkan bahwa tingkat kesulitan belajar perpajakan bagi mahasiwa tidak mempengaruhi motivasi dalam belajar materi perpajakan. Kesulitan belajar merupakan hambatan dalam aktivitas belajar mahasiswa. Aktivitas belajar yang terhampat dapat membuat proses dan hasil belajar menjadi tidak optimal. Hambatan belajar timbul secara internal maupun eksernal tidak mempengaruhi motivasi belajar yang dimiliki mahasiswa. Kesulitan belajar merupakan suatu kondisi yang wajar dan dapat

Idialami oleh setiap mahasiswa dalam mempelajari suatu materi perkulihan. Kesulitan yang timbul dalam aktivitas belajar tidak akan menyurutkan motivasi seseorang untuk mengusai materi.

\section{Perbandingan hasil penelitian dengan peneliti terdahulu}

Hasil penelitian terdahulu menyatakan bahwa tidak ada pengaruh yang signifikan kesulitan belajar perpajakan terhadap motivasi belajar mahasiswa. Berarti tingkat kesulitan belajar perpajakan tidak dapat mengubah motivasi belajar mahasiswa. Sedangkan, Hasil penelitian ini mendukung hasil penelitian sebelumnya yang menunjukkan bahwa tingkat kesulitan belajar perpajakan bagi mahasiwa tidak mempengaruhi motivasi dalam belajar materi perpajakan. Kesulitan belajar merupakan hambatan dalam aktivitas belajar mahasiswa. Aktivitas belajar yang terhampat dapat membuat proses dan hasil belajar menjadi tidak optimal. Hambatan belajar timbul secara internal maupun eksernal tidak mempengaruhi motivasi belajar yang dimiliki mahasiswa. Jadi hasil penelitian ini sejalan dengan penelitian terdahulu.

\section{PENUTUP}

\section{Kesimpulan}

Hasil analisis dan pembahasan bahwa tidak ada pengaruh yang signifikan kesulitan belajar perpajakan terhadap motivasi belajar mahasiswa. Berarti tingkat kesulitan belajar pajak tidak dapat mengubah motivasi belajar mahasiswa.Hasil Mann-Whiteney kesulitan belajar perpajakan terhadap motivasi belajar mahasiswa sebesar $\beta x y=-0,05$ dengan signifikansi 0,658 .

\section{Keterbatasan dan Saran}

Penelitian ini memiliki keterbatasan. Keterbatasan dalam penelitian ini adalah data yang digunakan adalah data sekunder dan bersifat kuantitatif. Berdasarkan kesimpulan yang telah dipaparkan, maka saran yang diajukan adalah penelitian selanjutnya di harapkan dapat menggunakan data primer,sehingga dapat mengetahui kendala atau permasalahan mahasiswa yang hasil belajarnya rendah. 


\section{DAFTAR PUSTAKA}

Lyness, D'arcy (2007). Learning Disabelities, http://kidsheald.org/teen/diseases_conditions/learning/learning_disabilities.ht $\mathrm{ml}$ diakses 15 Desember 2010.

Pujadi, Arko (2007). Faktor-faktor yang Mempengaruhi Motivasi Belajar Mahasiswa: Studi Kasus Pada Fakultas Ekonomi Universitas Bunda Mulia, Jakarta: Business \&Management Journal BundaMulia, Vol.3 No.2 September 2007

Purwanto, Ngalim. 2011. Ilmu Pendidikan Teoristis dan Praktis, Bandung: Remaja Rosdakarya

Rahmawati, Emi dan AdiDarmawanErvanto (2017). Pembelajaran Mata Kuliah Perpajakan Berbasis Kasus: Bukti Empiris dan Survei, Madura: Volume 11, No.2, Desember 2017

Setyawan,Cornelius Hery(2012). Peningkatan Hasil Belajar Perpajakan Melalui Media Taxi Snaders Pada Siswa Xi B Smk Pl Tarcisius 2, Semarang: JurnalPendidikanEkonomiDinamikaPendidikan Vol. VII, No. 1, Juni 2012 Hal. 53 - 66

Slameto (2003).BelajardanFaktor-faktor yang Mempengaruhinya, Jakarta: RinekaCipta

Sudrajad, Akhmad (2008). MembimbingKesulitanBelajarSiswa, http://akhmadsudrajat. wordpress.com/2008/01/25/kesulitan-dan-bimbinganbelajar/ diakses 5 Januari 2011

Suharyono, and Teguh Widodo. 2017. "Analisis Hasil Belajar Mahasiswa Dalam Mata Kuliah Komputer Akuntansi.” Jurnal Inovasi Bisnis.

Suharyono, Suharyono. 2019. "Pengaruh MYOB Test Clinic Terhadap Kompetensi Mahasiswa." Jurnal Analisa Akuntansi dan Perpajakan.

Wahyuni, EndahDwidan Lobby Loekmono (2006). Korelasiantara Gaya Belajar Akomodator dan Asimilator dengan Prestasi Belajar Kimia SiswaKelas X SMANegeri 2 Salatiga, Salatiga: JurnalKependidikan Vol.7 No.2 - Vol.8 No.1 Juli 2006 -Juni 2007

Wexley, Kenneth N., dan Gary A. Yuki (2003). Perilaku Organisasi dan Psikologi Personalia, Jakarta: Rineka Cipta

Yulianto, A.Ronydan Dewi Apriyani.Kesulitan Belajar Perpajakan dan Pengaruhnya terhadap Motivasi Belajar Mahasiswa Pendidikan Ekonomi 